INTERDISCIPLINARIA ARCHAEOLOGICA NATURAL SCIENCES IN ARCHAEOLOGY

A look at the region

\title{
PAPAVER. Centre for Human and Plant Studies of Postglacial Europe and Northern Africa, 2013-2015
}

\author{
Jaromír Beneša $^{*}$, Adéla Pokornáa , Alexandra Bernardováa ${ }^{a}$ Michaela Divišováa, Petra Houfkováa, \\ Ondřej Chvojka ${ }^{\mathrm{b}}$, Kateřina Kodýdkováa, Veronika Komárkováa, Klára Paclíkováa ${ }^{a}, K^{2}$ arel Prache, \\ Michal Preusz ${ }^{\text {, }}$ Kamila Lencováa ${ }^{\text {, Jan Novák }}{ }^{\mathrm{a}}$, Tereza Š́lková ${ }^{\mathrm{a}}$
}

\author{
${ }^{a}$ University of South Bohemia, Faculty of Science, Laboratory of Archaeobotany and Palaeoecology, Na Zlaté stoce 3, 37005 České Budějovice, Czech Republic \\ ${ }^{b}$ University of South Bohemia, Faculty of Philosophy, Institute of Archaeology, Branišovská 31a, 37005 České Budějovice, Czech Republic \\ ${ }^{c}$ Department of Botany, Faculty of Science, University of South Bohemia, Na Zlaté stoce 1, 37005 České Budějovice \\ ${ }^{d}$ University of West Bohemia, Faculty of Arts, Chair of Archaeology, Sedláčkova 15, 30614 Plzeň, Czech Republic
}

\section{ARTICLE INFO}

\section{Article history:}

Received: $28^{\text {th }}$ July 2015

Accepted: $2^{\text {nd }}$ September 2015

\section{Keywords:}

archaeobotany

palaeoecology

archaeology

South Bohemia

Europe

Africa

education

\begin{abstract}
A B S T R A C T
Papaver Centre was constituted in 2013 at the University of South Bohemia in České Budějovice, Czech Republic. The name of centre represents common and interesting genus of plants which is distributed from Northern Africa across Europe to the polar latitudes. The aim of the Papaver Centre is to develop ties within the interdisciplinary team consisting of paleoecologists, archaeologists, and vegetation ecologists in order to create an effective space for the study of climatic, cultural as well as landscape changes. This paper describes recent educational and scientific activities of the centre. One of main results is realization series of international lectures of top scientists, which substantially improved capabilities of members in the Laboratory of Archaeobotany and Palaeoecology.
\end{abstract}

\section{Introduction}

In the beginning of 2013, the Ministry of Education and the European Social Fund of the Czech Republic granted the Laboratory of Archaeobotany and Palaeoecology (LAPE) financial support to create a new body called Papaver, Centre for human and plant studies in Europe and Northern Africa in the postglacial period. The Papaver Centre is not regarded as a regular organizational unit, but as temporally-limited grouping of researchers, teachers and students from LAPE and the Department of Botany of the Faculty of Science and the Institute of Archaeology, Faculty of Philosophy from the University of South Bohemia in České Budějovice.

The aim of the Papaver Centre project has been to develop ties within an interdisciplinary team, consisting of

*Corresponding author. E-mail: benes.jaromir@gmail.com paleoecologists, archaeologists, and vegetation ecologists, in order to create an effective space for the study of climatic, cultural, as well as landscape, changes in vegetation and crops along a gradient from northern Africa, across central Europe, and up to the coldest areas of the north. The purpose of the project has been to connect and coordinate key experts of international repute and thus provide the South Bohemian team the dynamics and impulses for development of top quality research by means of internships, lectures, workshops, conferences, as well as by everyday communication tools. The project has created a suitable environment for young researchers and $\mathrm{PhD}$ students by including them in clearly-defined structures of ongoing research on attractive topics. Team activity has been based on three panels in the fields of environmental archaeology, paleoecology, and vegetation ecology. The aims of such activity have been to coordinate with each other and create a team producing synergistic outcomes. A further aim of 
the project has been to stabilize and extend the operational range of the research group, which connects archaeological directions in landscape development research with the latest trends in botany. The research centre bears the name of the genus of poppies (Papaver), the representatives of which are distributed from the coldest areas on Svalbard to the warmest of northern Africa, and thus represents the region targeted by the project's research interests.

\section{Papaver Centre and research development in 2013-2015}

In accord with the project's idea to create conditions for top science, the members of the Papaver team actively contributed to the scientific goals of their different projects. The synergy between several active research grants and the Papaver project was extraordinarily useful. The support has enabled interdisciplinary space to be created for several specific palaeoecological, archaeobotanical and botanical research tasks. The Papaver project has been led by the head of the centre, archaeologist and archaeobotanist Jaromír Beneš, and the scientific supervisor for the whole team, botanist and vegetation ecologist Karel Prach. The Papaver team itself has been organized into three thematic panels. The paleoecological group, led by J. Novák, has integrated and organized activities connected with a multi-proxy approach focused on the reconstruction of the Holocene vegetation changes in terms of vegetation, climate, and human impact upon environmental changes throughout Europe (Bešta et al. 2015). Up to now the scholars involved in the Papaver project have contributed into many multi-proxy palaeoecological and archaeobotanical studies in central Europe (Hlásek et al. 2014; Hlásek et al. 2015; Chvojka et al. 2014; Pokorná et al. 2014). The attention of the project has also been focused on the anthracological research at many important archaeological sites (Novák 2014a; Novák 2014b). Anthracology is an effective method for the study of macrovegetation in the landscape (trees and shrubs). Other anthracological studies highlight the importance of pedoanthracological research for the reconstruction of woodland history; for example, in the sandstone area of North Bohemia (Prostředník et al. 2014).

The environmental archaeology group has been led by J. Beneš. This panel has focused on research into the Mesolithic/Neolithic transition in central Europe; however, the younger post Neolithic periods of human impact on nature in prehistoric Bohemia and Moravia have not been omitted. The aim of the Papaver team has also been to investigate Mesolithic hunter-gatherers through a broad interdisciplinary approach. The members have participated in a range of archaeological excavations, occuring in certain regions of the Czech Republic, namely the Třeboň basin in south Bohemia, and the north Bohemian pseudokarst area of Bohemian Paradise (Šída et al. 2014; Divišová, Šída 2015). Apart from the excavations themselves and artefact analyses, a number of palaeoecological and archaeobotanical analyses have formed integral components of the research. A variety of questions regarding former human behaviour, environment, plant use, human impact on the landscape, etc., are being investigated using the tools of environmental archaeology, such as pollen analysis or analysis of plant macroremains. In addition, the issue of the last hunter-gatherers in the region and their transition to farming, which is of special importance, has been addressed by examining specific sites together with artefactual and ecofactual material recovered from sediments dated from the Mesolithic onwards.

A second connection between environmental archaeology and archaeobotany has been created in the case of the Bronze Age period and Early Iron Age period in south Bohemia. The aim of our research has been the notification of current macro-remains analysis of the prehistory cultural sediments in the region of South Bohemia. The analysed assemblage consists of a cluster of sites dated in a time span from the Late Neolithic to the Early Iron Age period. The samples have been obtained during the course of salvage, as well as scholarly, excavations between the years 2005 and 2015 (Šálková et al. 2014). In our research, macroremains analysis represents another source of interpretation of archaeological features, infills, and cultural layers, and makes possible the reconstruction of the palaeoeconomy of settlement areas (e.g. housing, economy, structure of utility plants and weeds, burial rites), as well as the natural environment in the background of human sites (e.g. Šálková et al. 2015; Hlásek et al. 2014; Chvojka et al. 2014; Hlásek et al. 2015; Fröhlich et al. 2014).

The third direction of research in the environmental archaeology panel has been the study of the relationship of plants and humans in the medieval period and Early Modern Age in historical Czech lands. The archaeobotanical attractiveness of such research in these relatively young periods is that it increases a direct and unmistakable link to the present we live in now. This is especially obvious in the comparative research into the development and changes in individual types of cereals used during the malting process and subsequent brewing between the $13^{\text {th }}$ and $18^{\text {th }}$ centuries. As a result, we have managed to penetrate specific production processes, and the qualitative and quantitative aspects of brewing and malting before the advent of modern technology (Kočár et al. 2015).

Medieval and Early Modern agriculture as a cardinal factor in the transformation of landscape and humaninduced changes in vegetation has been under the focus of Papaver Centre members. In the case of terraced fields in Malonín (South Bohemia), we have established a new methodology in how to date such changes (Houfková et al. 2015). Thanks to another research grant, we have performed archaeological excavations of the long-stripped fields in the abandoned village Malonín. Our approach has consisted of a combination of information from different sources such as historical documents and maps, chronologies based on the dating of archaeological artefacts, ${ }^{14} \mathrm{C}$ data, and the assignment of ${ }^{210} \mathrm{~Pb},{ }^{137} \mathrm{Cs}$ concentrations. Our results have proved that the current pattern of field margins in the former village of Malonín is High Medieval in origin. As 
recent landscape patterns in many villages in marginal areas of central Europe can be based on man-made structures originating in the Medieval Period, we conclude that the memory of the medieval landscape remains very strong. Our results have provided arguments for the preservation of such defined landscape units; this could lead to a conservation of both long-term historical pattern and recent biodiversity bound to its exact combination of landscape elements.

The issue of the Medieval and the Early Modern economy and ecology in historical towns has also been very attractive. Members of the Papaver Centre have studied two sites: Písek-Bakaláře (the Medieval secondarily filled-in well; Šálková et al. 2015) and České Budějovice, Krajinská street 7 (the Medieval cesspit; Čapek et al. 2015). In those times wells were very often secondarily used as cesspits: because of water contamination or changes in water regimes. Various aspects of human life and behaviour have been reflected in the waste disposal and storage inside "Well 1" in PísekBakaláře. It has been possible to detect imported material of different origins and to reconstruct the environment of the town's background (meadows, fields, gardens, forests), as well as animal rearing (cattle, sheep, pig, horse, dog, cat), crops grown (cereals and fruits), and waste management practices (Šálková et al. 2015). The faecal infill of the cesspit in České Budějovice, Krajinská 7 was characterised by the macroremains of utility plants which reflected the food strategy of medieval burghers (Čapek et al. 2015).

Since the Early Modern world was not only about production but also about consumption, a pilot study on the everyday life of selected "consumers" in the south Bohemian town of Czech Krumlov (UNESCO) has been created with an emphasis on the reconstruction of the eating habits of townspeople during the $17^{\text {th }}$ century (Preusz et al. 2014), using the testimony of archival sources, archaeology, archaeobotany and archaeozoology. Our investigation has revealed that changes in the traditional stereotypical diet and social customs have crystallized over the centuries, and has opened up entirely new perspectives in the study of diversity in the eating habits of people in the Medieval and Early Modern period. In this respect, the Papaver Centre has carved out a suitable space to bring greater synergy between history, archaeology and the natural sciences.

A crucial topic of the Papaver Centre has been to create an organizational milieu for the study of north African and Mediterranean crops and other materials of plant origin, and their transmission to central Europe from the end of the last glacial to the Early Modern period. Archaeobotanical investigation in NE Africa already has a tradition in LAPE. We have closely cooperated with a multidisciplinary archaeological team led by the Czech Institute of Egyptology, Faculty of Philosophy and Arts, Charles University in Prague. Several members of our laboratory have already taken part in expeditions to Egypt since 2005, and in Sudan since 2011. Among localities of our own interest we can mention Abusir and the oasis of Bahariya in the Western Desert (Egypt), and the Sabaloka Mountains in Sudan. The most important methods in African archaeobotany have been the analysis of plant seeds/fruits by A. Pokorná and the analysis of wood and charcoal by J. Beneš and J. Novák (Krejčí et al. 2014).

A survey of recent vegetation in the archaeological sites of Lazio has been held during the two vegetation seasons of 2014 and 2015. In consultation with Italian specialists, a list of plant species (incl. photo-documentation) related to the archaeological area of Santa Severa and Santa Marinella has been created. One of the first applications of this list has been for a short botanical guide for students that will be used for education purposes during the SIS-School of interdisciplinary studies in September 2015. Members of the Papaver team have studied the local vegetation in Lazio as a witness to its ancient history. The analysis of its present vegetation has enabled tentative extrapolations as to how the vegetation could have looked in Roman times (Figure 6).

Recently, new methods have been introduced in cooperation with our laboratory: namely the analyses of starch and plant phytoliths. Our members have taken part in field expeditions to Africa on a regular basis. Field work has comprised the sampling of archaeological contexts as well as the creation of reference collections, and ecological studies of recent vegetation. We have established cooperation with a local botanist in Sudan to enable (among other things) the more effective application of knowledge about modern plant behaviour when interpreting past environments.

The vegetation ecology panel, led by Karel Prach, has mostly focused on the search for current relations between a diversity of the flora and vegetation in a wider geographical context. The panel leader K. Prach has long focused on vegetation dynamics, succession processes, restoration ecology, and ecosystem restoration. Special attention will be paid to invasive plants resulting from contemporary ecological and social changes. One of the main efforts in this sense is the preparation of a paper (Kočár et al. in prep.), concerning a checklist of wild-growing herbaceous plants in the prehistory of the Czech Republic. This list of wild plants is based exclusively on archaeobotanical evidence and will be available for evaluation by botanists for the first time. The Papaver project has also supported the study of vegetation in abandoned fields as specific biotopes under long term human impact (Prach et al. 2014).

The arctic ecology of plants team has focused on several topics - vegetation dynamics, pollen deposition and the relationship between species and geomorphology. The first topic of focus has been the palaeoecological analyses of soil and lake cores retrieved in the field. Pollen deposition has been monitored through a system of pollen traps as part of a pollen monitoring program that is widely used within Europe (http://www.pollentrapping.net/vegmapping.html). Pollen traps have been newly installed in the central part of Svalbard along with vegetation mapping around the traps. In 2014 vegetation mapping was also finished in Abisko, Sweden, where traps have already been in operation. The relationship of vegetation and geomorphology has been studied according to species traits (species composition, cover, biomass) and the characteristics of the terrain (morphology, slope, aspect, flow accumulation) as retrieved by detailed LIDAR scanning. 


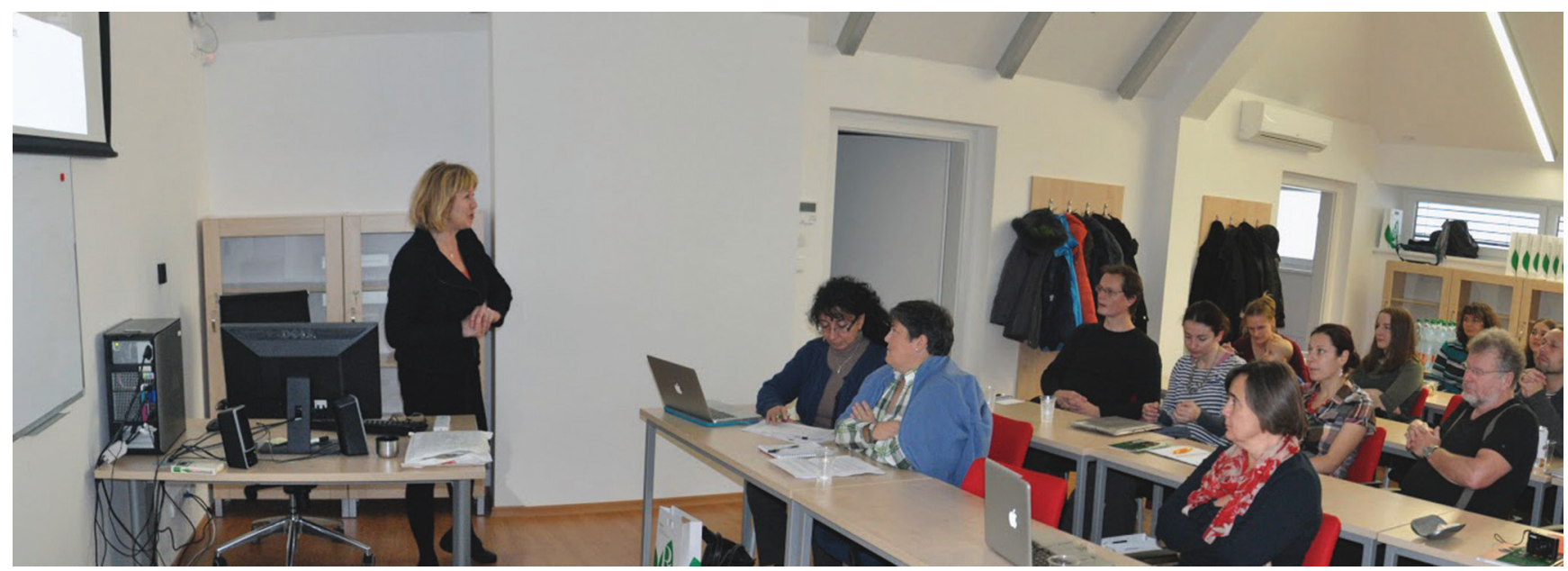

Figure 1. Sabine Karg is lecturing during the Papaver Centre introductory meeting. Photo Klára Paclíková.

\section{Papaver Centre education and international team building programme}

A core part of the Papaver Centre project has been the scientific educational program for Czech members of the Papaver team, which has consisted of meetings, field workshops, summer schools and teaching weeks held by specialists from Denmark, Germany, Italy, Japan, Sweden and United Kingdom. Archaeobotanists and paleoecologists from top European institutions have taken part for the first time as a team in the Introductory Papaver meeting 2013 (Figures 1 and 2). The education program terminated the international Conference of Environmental Archaeology in February 2015 in České Budějovice.

\subsection{Field workshops and summer schools}

Field workshops and summer schools have been organized in order to improve the coordination and synergy between archaeology, archaeobotany and palaeoecology. Three archaeological field projects were chosen as subjects for training and archaeobotanical sampling activity.

\subsubsection{Schwarzenberg Lake Mesolithic Occupation field workshops}

Two field workshops were led by Petr Š́da in the area of the former Schwarzenberg Lake in South Bohemia in 2013 and 2014. These intensive, on-site seminars were focused primarily on exploring Mesolithic communities through excavation. Modern approaches and field techniques in hunter-gatherer field research were presented and discussed. In addition, an experimental archaeology programme aimed at the reconstruction of pre-Neolithic cooking methods was conducted (Figure 3).

\subsubsection{Tuchlovice Iron Age Wetland Site field workshops}

In seasons 2013 and 2014, in collaboration with the Department of Prehistory and Classical Antiquity of the National Museum Prague, two field workshops were

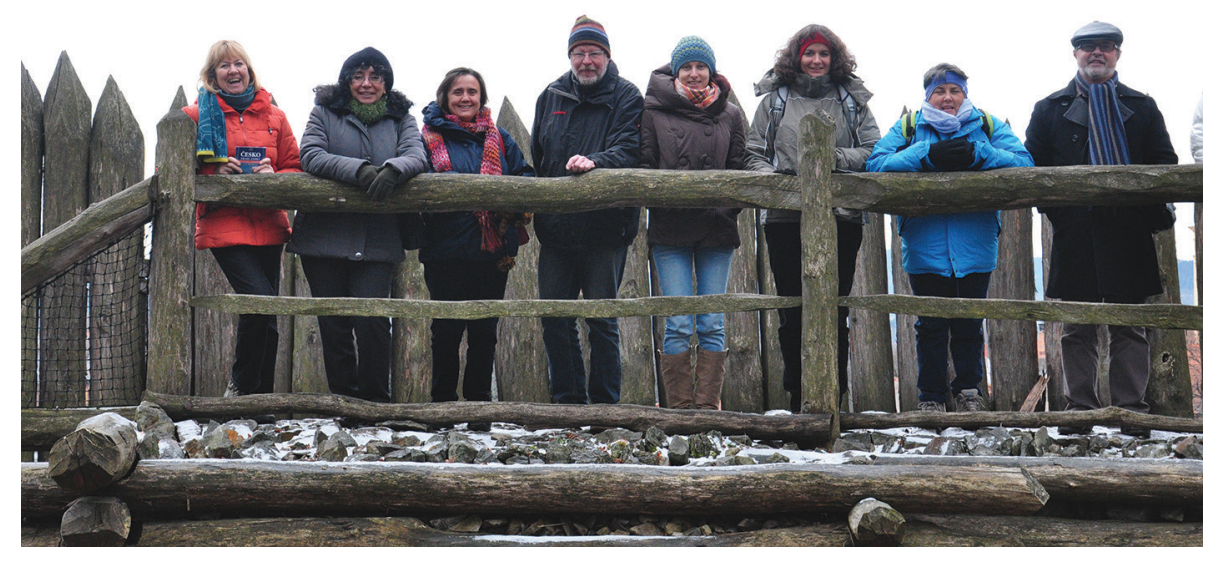

Figure 2. Members of Papaver Centre international introductory meeting: From left: Sabine Karg, Anna Maria Mercuri, Laura Sadori, Manfred Rösch, Kamila Lencová, Veronika Komárková, Leonor Peña-Chocarro, Jaromír Beneš. Photo Klára Paclíková. 
Figure 3. Petr Š́́da during preparation of cooking experiment in Schwarzenberg Mesolithic workshop, Czech Republic. Photo: M. Divišová.

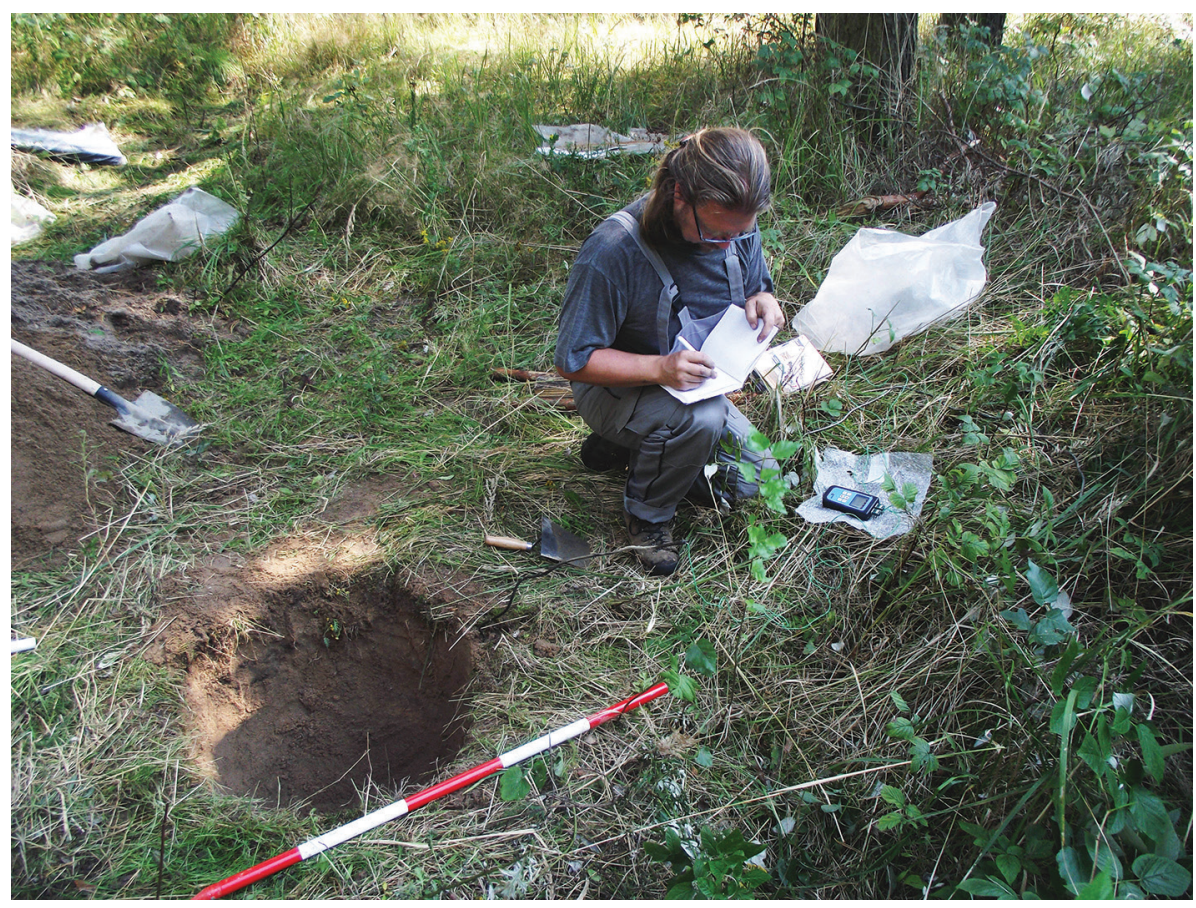

conducted during the Tuchlovice archaeological excavation in the floodplain of the Tuchlovický stream in Central Bohemia. This action loosely followed the salvage excavation and findings of the years 1966-1968, during which exceptionally well-preserved finds from organic materials, especially wood, were discovered in the stream floodplain settlement from the Roman period. These workshops stimulated the mutual transfer of knowledge and skills between archaeologists and natural scientists. Papaver team members in the field learned about the methodology of archaeological research in the river floodplain and performed sampling for the analyses of wood items, plant macroremains, and pollen.

\subsubsection{Archaeological summer schools in Netolice}

The Papaver Centre organized between 2013 and 2015 three summer archaeological schools in Netolice, close to České Budějovice in South Bohemia. Na Jánu fortified settlement is situated in Netolice. The site and its surroundings are being explored by several institutions, including the University of South Bohemia (Beneš et al. 2012). Archaeological explorations of the Netolice fortified settlement have been systematically going on since 2000, when the first extensive excavations of the fortified settlement's ruins and graveyard were carried out. This fortified settlement is generally classified as one of the Přemyslid Early Medieval administrative castles in the South Bohemia region, built at the beginning of the Czech state during the $10^{\text {th }}$ century. As one of the administrative centres in South Bohemia, the fortified settlement was built in the ancient manner before the time of stone castles and towns. The castle's location on the trade route between Linz and Prague gave it a particularly favourable position for growth.

Archaeological investigations have discovered a church, cemetery and a complex settlement structure. Researchers and students of the Institute of Archaeology and Laboratory of Archaeobotany and Palaeoecology organized during 2013-2015 three Archaeological summer schools there (Figure 4), which offered not only scientific field education in bioarchaeological and archaeobotanical disciplines, but also attracted the public to visit open lectures and costume days, where it was also possible to taste the results of the useful-plant experimental cooking according to accepted archaeobotanical knowledge. During the summer the Papaver Centre organized a full schools education programme in archaeobotany and palaeoecology. This activity comprised onsite sampling and training analysis in the area of the Netolice hillfort acropolis, but also palaeoecological training in its hinterland.

\section{Papaver Centre international teaching weeks}

One of the most attractive and visible features of the Papaver Centre has been its teaching weeks, all of which have been guided by top European researchers as listed below. The aim of the courses was to improve the knowledge of the Czech team members in theoretical perspectives and practical skills. We describe the content of the courses completed in the following paragraphs; these courses attracted not only Papaver Centre members, but also other students and researchers from the Czech Republic.

Sabine Karg, Copenhagen, Denmark, 10.-13. 2. 2014, Staple and wild food resources during Neolithic and Medieval Times in Northern and Central Europe. In this course, Sabine Karg lectured about the systematics of cereals and pulses archaeobotany. The connection between practical archaeobotany and archaeological explanation was a common feature in Sabine's teaching. A considerable portion of the 


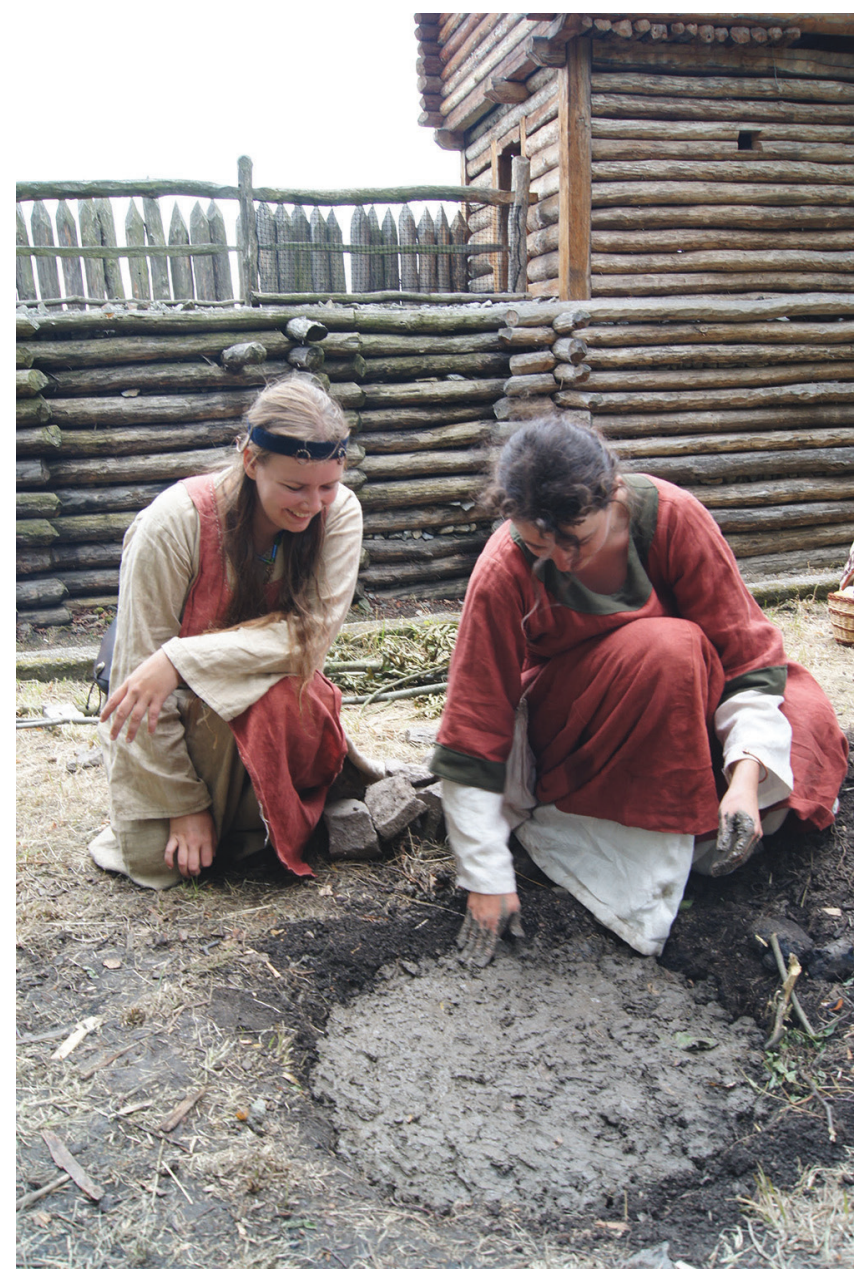

Figure 4. Archaeobotanical cooking experiment during Archaeological summer school 2013 in Netolice, Czech Republic: From left: Monika Hrušková, Michaela Divišová. Photo Martin Pták.

northern and central European experience was demonstrated. Special attention was paid to prehistoric flax technology.

Laura Sadori with Alessia Masi and Caterina Pepe, La Sapienza, Roma, Italy, 19.-21. 5. 2014, Archaeobotany and Palynology of the Mediterranean. Laura Sadori with her two assistants lectured about one of the crucial topics of the Papaver Centre: plants and the human world of the Mediterranean. The lectures were concentrated on the pollen analysis of lake sediments, but also on climatic development, which has been recorded in the stable light isotopes of fossil plants. Additionally, some valuable environmental records in archaeological areas such as Portus Traianus were demonstrated.

Manfred Rösch, Landesamt für Denkmalpflege im RP Stuttgart, Gaienhofen-Hemmenhofen, Germany, 21.-24. 5. 2014, Former agriculture, lake sediments and pollen analysis in Germany and the western Alpine region. Manfred Rösch is an archaeobotanist with a special focus on the Alpine region in the postglacial period. He lectures not only covered pollen analysis and plant macroremains determination, but also environmental archaeology as practiced today in his region, with special attention to prehistoric agriculture. Special attention was also paid to unique bronze vessels of valuable archaeological situations and their bioarchaeological potential.

Anna-Maria Mercuri with Assunta Florenzano, University of Modena and Reggio Emilia, Italy, 4.-6. 6. 2014, Palaeoenvironmental studies of the Mediterranean and Sahara. Lectures in archaeobotany, palynology and palaeoenvironmental studies were targeted on some attractive regions in Italy (North Italian Bronze Age terramaras, Basilicata in Southern Italy), as well as on the prehistoric human occupation of the Sahara. Special attention was paid to paleoclimate development and cultural trajectories in northern Africa and southern Europe. Particularly fruitful were the archaeobotanical case studies from countries that are almost inaccessible today, for example, from Niger. Lectures were followed by practical demonstrations with pollen samples and macroremains.

Oliver Nelle, Landesamt für Denkmalpflege im RP Stuttgart, Gaienhofen-Hemmenhofen, Germany, 12.-13. 2. 2015, Wood and wood charcoal analysis. The aim of this course was to get acquainted with methods of wood and wood charcoal analysis. The course addressed several aspects of taking samples in the field, sample processing, microscope work, and data analysis. The potentials and limitations of wood and wood charcoal analysis were also discussed, as well as wood anatomy and the application of microscope wood determination. In addition, other methods of anthracology (charcoal analysis) were also introduced, such as fire history reconstructions by the analysis of peat or lake sediment micro- and macrocharcoals.

Peter Poschlod, University Regensburg, Germany, 3.-5. 3.2015, Driving forces of the history of the central European/ German man-made landscape and selected habitats. A holistically conceptualized course focused on Holocene climate, human diseases, wars, human spirit, technical progress and economic changes in European agricultural policy. In these lectures an entire history of central European calcareous grasslands were demonstrated, as well as specific localities affected by humans such as pig grazing areas and all former diverse habitats. The history, ecology and actual situation of transhumance in the (French) Alps were also presented.

Dorian Fuller, University College London, United Kingdom, 6.-8. 3. 2015, Growing Societies: the archaeobotany of food production and globalization of agriculture. The lectures were focused on a global perspective in archaeobotany and archaeology, for example, on the changes in pastoral pathways to plant domestication in Africa. The second main issue dealt with was the domestication of rice in eastern Asia and the ethnobotany of rice use. The topic of globalization played a central role in the lecture about the archaeology of a used planet. A chief concern of the lectures was on the material culture of Asia and northern Africa in connection with the use of economic plants.

Marie-José Gaillard, Kalmar University, Sweden, 8.-10. 4. 2015. Pollen-based reconstruction of vegetation 
Figure 5. Italian archaeologists take archaeobotanical samples from submerged well in Etruscan seaport Pyrgi, Italy. Material from the well is analysed by Papaver Centre members. Photo Flavio Enei.

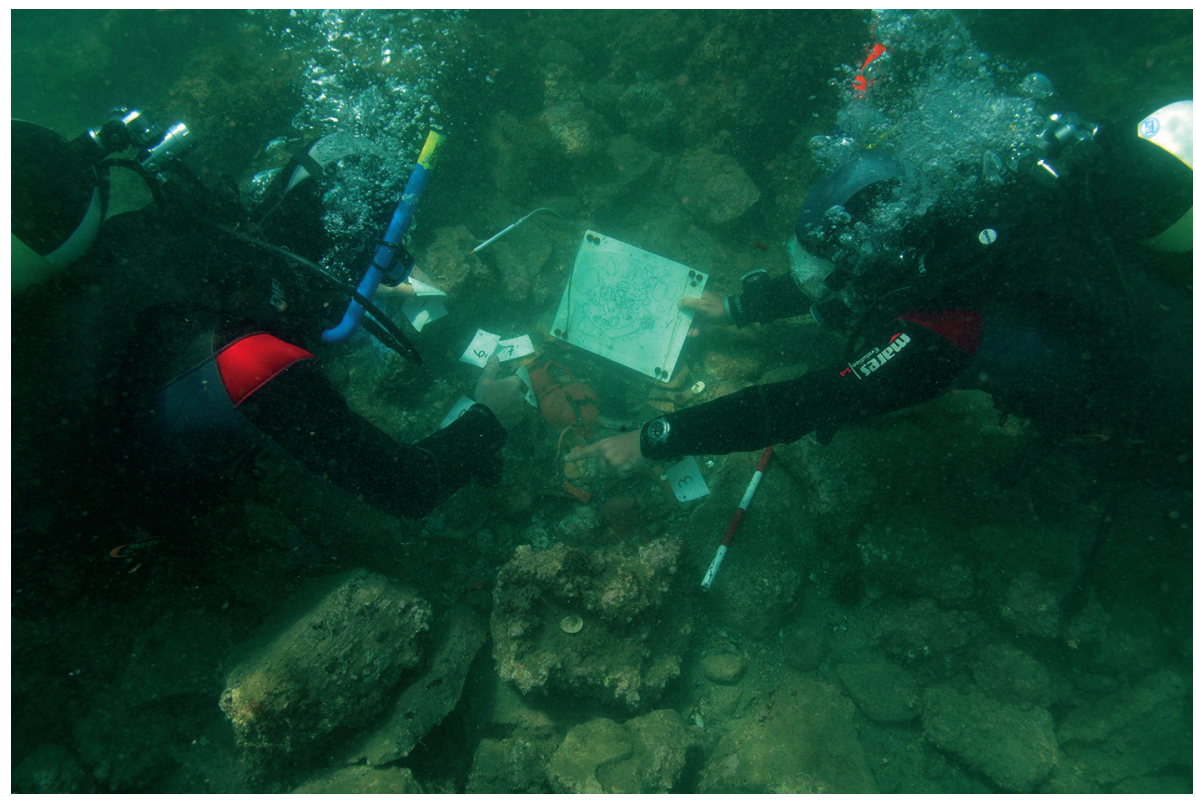

abundance/cover: theory and practice. The course covered the theory of pollen analysis, including models of pollenvegetation relationships and pollen dispersal and deposition, and application of the "Landscape Reconstruction Algorithm" of Shinya Sugita for pollen-based reconstructions of vegetation abundance/cover. The course included half- day lectures and half days of group discussions and plenary sessions on the potential of models and their use in research.

Takeshi Nakagawa, Ritsumeikan University, Japan, 19.-22. 5. 2015, Quaternary climate changes: standard theories and challenging the status quo. These lectures were targeted on climate development in the Late Glacial and postglacial development in order to explain standard and alternative theories about the Younger Dryas. The last forty thousand years of climatic development were explained in the context of the Suigetsu lake environmental record in Japan and also in the global context of radiocarbon-dating calibrations. Detailed climate reconstructions were discussed in the context of human cultural development.

\section{Creating new perspectives: educational exchanges of Papaver Centre members}

Two institutions, out of many, that were included in the Papaver project were the University La Sapienza in Rome and the University of Modena and Reggio Emilia in Modena. Cooperation with members of La Sapienza university

Figure 6. Landscape scenery evocating the Roman period countryside, Northern Lazio close Sasso, Italy. Photo K. Prach.

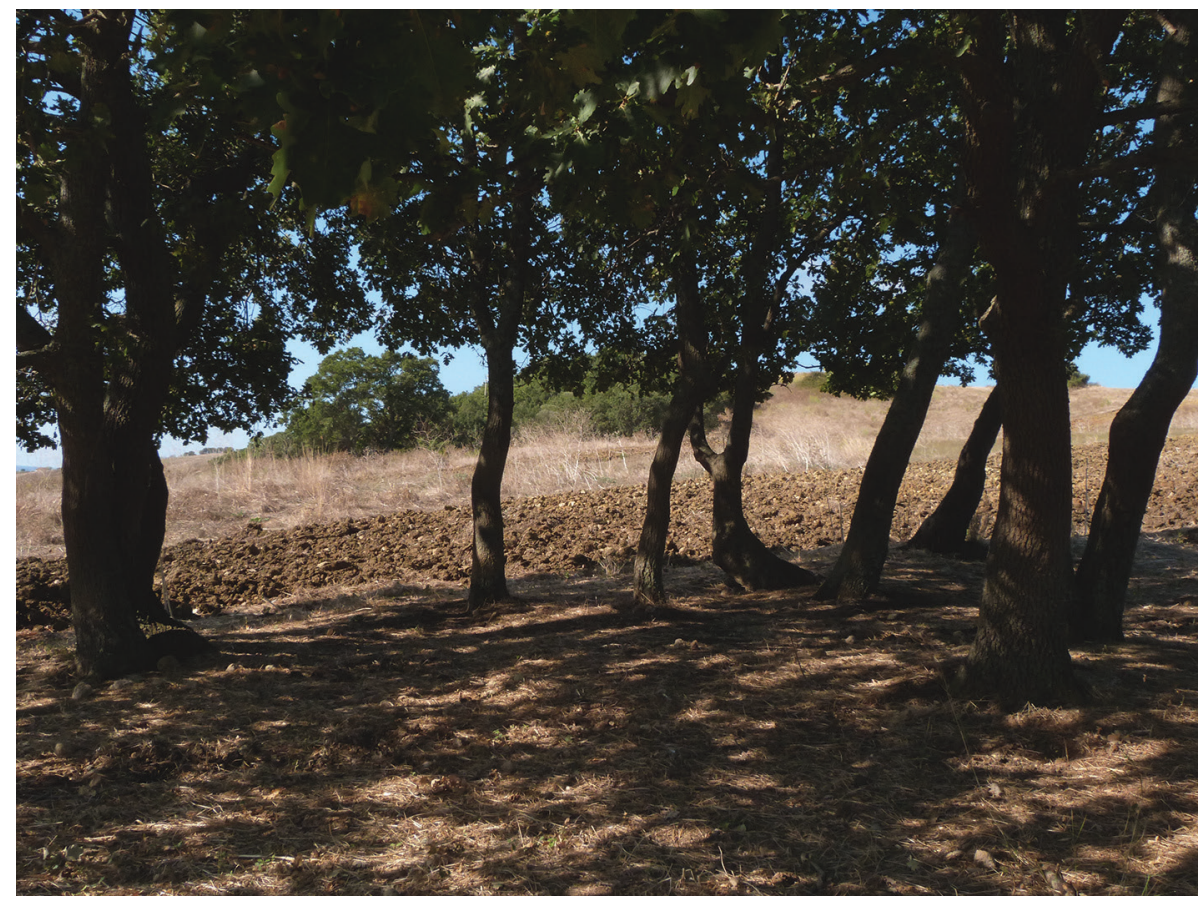




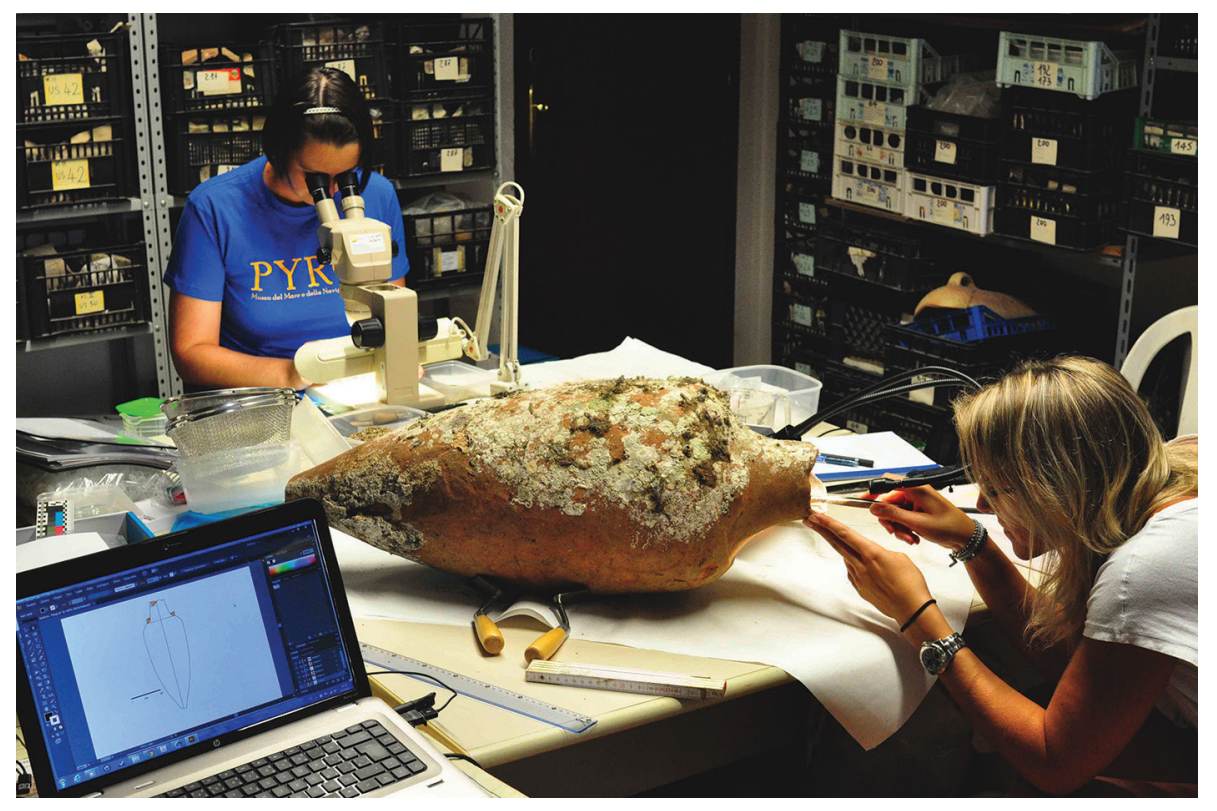

Figure 7. Kateřina Kodýdková and Klára Paclíková are trained in the bioarchaeological sampling methods of the Roman amphora content in Pyrgi. Italy. Photo Jaromír Beneš.

have long preceded the start of the Papaver project, since Jaromír Beneš has given several lectures there from 2011 onwards. The initiation of the Papaver Centre has enabled the cooperation between LAPE and La Sapienza to be extended. The opportunity to study abroad at the Museo del mare e della navigazione antica in Santa Severa under the auspices of La Sapienza has become a great contribution for Czech members of Papaver. Under the supervision of Italian palaeoecologists and archaeologists, Czech Papaver members have been able to become familiar with the methodology of underwater excavations (Figures 5 and 7), with the problems of processing and interpretating palaeoecological data, and, above all, with the different approaches of Italian scientists.

As an example we could mention two interesting sites of archaeological excavation where international teams have cooperated. The first site is the former Etruscan harbour of Pyrgi, in presen-day Santa Severa (Enei 2013a). The harbour and city, that are these days about 1-10 metres under the sea, used to be one of the most important points in ancient Italy for international maritime trade, being a gateway to the Etruscan realm. The second excavated site includes a roman villa in the city of Castrum Novum, in present-day Santa Marinella (Enei 2013b). This city was built along the sea, on the road known as the Via Aurelia, and soon after was inhabited by rich Romans (Desibio et al. 2015). In both cases, Czech members of the Papaver Centre have mostly contributed through environmental analyses - analysis of plant macro- and microremains (Kodýdková et al. 2013). The knowledge and methodology acquired by the Czech team has been essential.

Members of the Papaver Centre have visited the National Corporation for Antiquities \& Museums (NCAM) in Khartoum, Sudan. They have contacted archaeologists from Sudan who are interested in the multidisciplinary approach to

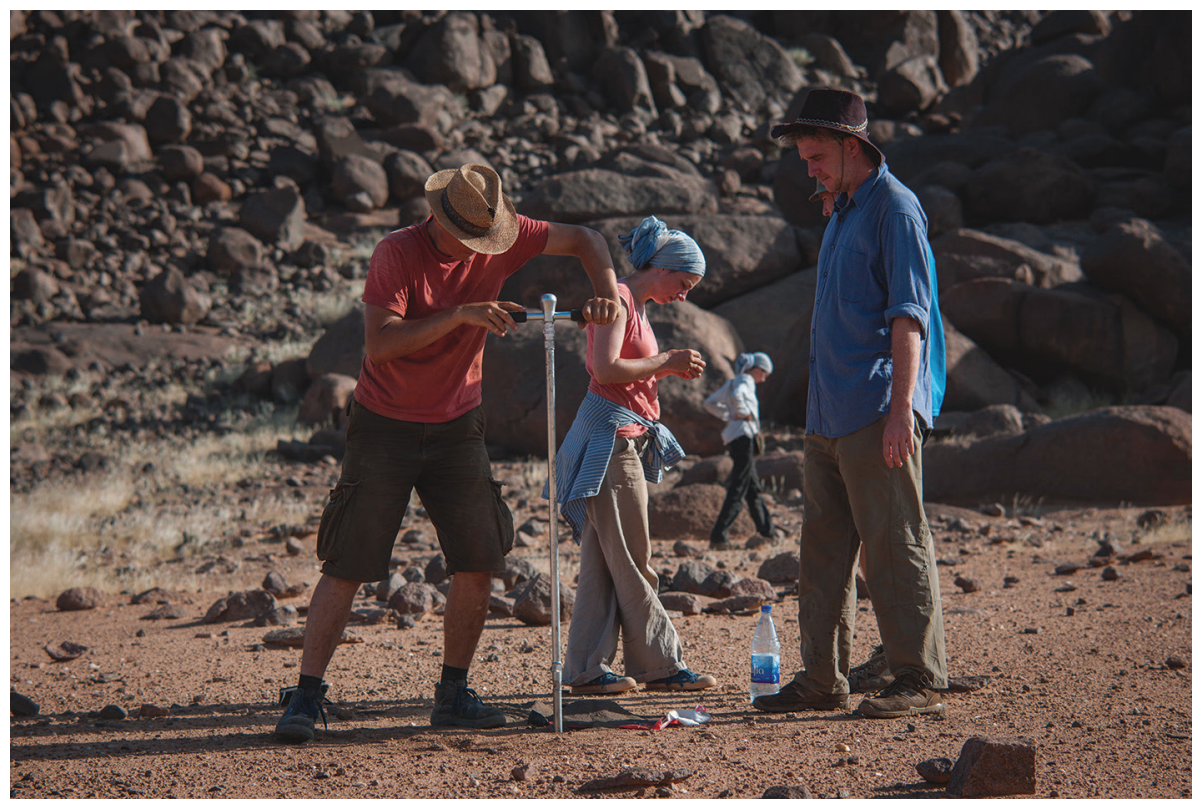

Figure 8. Study of humans' and vegetation past is an important part of archaeobotanical investigations of Papaver Centre in Sudan. Members of Papaver Centre sampling soil for environmental analyses. From left: Ladislav Varadzin, Lenka Suková, Jan Novák. Photo Petr Pokorný. 
Figure 9. Conference of Environmental Archaeology, February 2015, České Budějovice, Czech Republic. Photo Klára Paclíková.

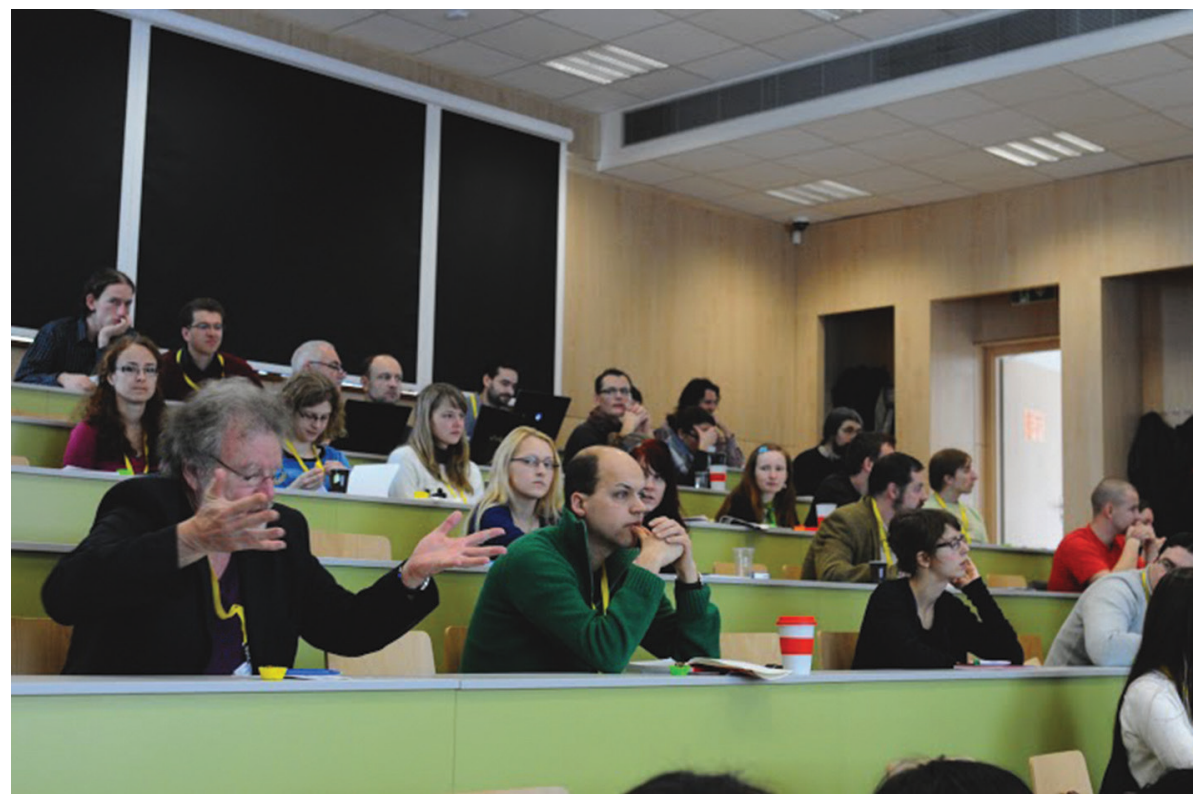

archaeological investigations and in questions associated with the history of agriculture and past climate reconstruction. We have also participated in field archaeological investigations in the Sabaloka Mountains near the $6^{\text {th }}$ Nile Cataract, provided by NCAM in cooperation with the University of Khartoum. During the excavations we have had the opportunity to meet different methods of archaeobotanical work in arid environments, as well as various sampling strategies and interpretations of environmental indicators (Figure 8). In cooperation with a local botanist we have had the opportunity to collect specimens for a reference collection of seeds, which is a fundamental tool for further archaeobotanical determinations. Our stay in Sudan has been very beneficial: both from the point of view of methodology and the establishment of contacts with local specialists. Our experiences with the specific conditions of arid NE Africa may be further utilised in our Laboratory for the archaeobotanical examination of material from associated territories (e.g. Egypt and Sudan).

Members of the Papaver Centre have also obtained a better knowledge regarding archaeobotany in Israel, namely at the Bar Ilan University in Ramat-Gan, where the famous archaeobotanical laboratory under the leadership of Ehud Weiss is located. The purpose of our study stay at Bar Ilan was to become acquainted with their laboratory practice, develop contacts for future research in the Czech Republic, and moreover visit key archaeological sites related to the origins of agriculture. The Czech team was able to look around Jericho, Ohalo, Ain Mallaha, and the caves of Mount Carmel, among several other locations.

\section{6. $11^{\text {th }}$ Conference of Environmental Archaeology (CEA), February 2015}

The $11^{\text {th }}$ conference of Environmental Archaeology took place between the $9^{\text {th }}-11^{\text {th }}$ February 2015 in
České Budějovice (Figure 9). Up to now it has been a traditional conference interconnecting archaeobotanists, palaeoecologists and vegetation scientists together with archaeologists. Up until the 2014 conference the focus has been on Czech, Slovak (and Polish) scientists only, the conference language having been Czech. However, in 2015, thanks to the PAPAVER project, the conference has become international. Though a considerable proportion, more than one hundred, of the participants were still from the Czech Republic, there were now participants from Germany, Italy, Estonia, Russia and Iceland also taking part. The topic of the conference - "LIFE IN FLUX - Humans, animals and plants in postglacial ecosystems of Europe and northern Africa"- was connected with the scope of the whole PAPAVER project. Particular sections were also similarly structured - from questions regarding vegetation development during the Holocene, Mediterranean and African Archaeobotany, to environmental archaeology in general (Bernardova, Kodýdkova (Eds.) 2015).

The conference was divided into several sections. The first section presented the issue of multidisciplinarity in Holocene investigations within the perspective of European archaeobotany. The second set of presentations and posters discussed African archaeobotany and environmental archaeology, in particular, in Sudan, Niger and Egypt. The last section was more general, bringing together diverse contributions from individual methods of analysis of prehistoric sites to a multiproxy approach in current archaeology.

\section{Concluding remarks}

The creation and work of the Papaver Centre has been an important step in several ways. At an internal university level it has created a useful working space - integrating archaeobotanists and palaeoecologists who operate in field research with archaeologists in general. The long-term 
financial and logistical support has enabled the growth and scientific potential of the Laboratory of Archaeobotany and Palaeoecology, and the young Institute of Archaeology, to be realized. The teaching weeks of invited top world scientists have, in particular, accelerated the research power of young members of the Papaver Centre team and enabled them direct experience of progressive directions of investigation. The Papaver Centre project has finally generated new scientific plans and stimulated new grant proposals. Last, but by no means least, the Papaver Centre in 2013-2015 has been able to systematically support this journal, Interdisciplinaria Archaeologica - Natural Sciences in Archaeology.

\section{Acknowledgements}

This article is supported by the grant 'Papaver. Centre for human and plant studies in Europe and Northern Africa in the postglacial period,' reg. no: cz.1.07/2.3.00/20.0289. The Papaver Centre cooperates with several research projects such as the Prior the Neolithic Project.

\section{References}

BEŠTA T., NOVÁK J., DRESLEROVÁ D., JANKOVSKÁ V., BERNARDOVÁ A., LISÁ L., VALENTOVÁ D. 2015: Mid-Holocene history of a central European lake: Lake Komořany, Czech Republic. Boreas 44.3, 563-574.

BENEŠ, J., PTÁK, M., DOBISÍKOVÁ, M., HOJEROVÁ, H., HOUFKOVÁ, H., KUTÍLKOVÁ, P., PARKMAN, M., ŠÁLKOVÁ, T., ŽĎÁRSKÝ, E. 2012: Výzkum hradiště Na Jánu v Netolicích v krajinných, antropologických, genetických a artefaktuálních souvislostech (In Czech) - Die archäologischen Forschungen auf dem Burgwall "Na Jánu" in Netolice in Verbindung mit landschaftsökologischen, anthropologischen und genetischen Untersuchungen. Archeologické výzkumy v jižnich Čechách 25, 265-277.

POKORNÝ, P., POKORNÁ, A. 2015: Common Plants of the Western Desert of Egypt by Petr Pokorný and Adéla Pokorná. [online]. Available from: http://westerndesertflora.geolab.cz/. [Accessed 2015-02-04].

BERNARDOVÁ, A., KODÝDKOVÁ, K. (Eds.) 2015: $11^{\text {th }}$ Conference of Environmental Archaeology. Book of Abstracts. University of South Bohemia in České Budějovice. České Budějovice.

ČAPEK, L., CHVOJKA, O., KODÝDKOVÁ, K. BENEŠ, J., HOUFKOVÁ, P., MYŠKOVÁ, E., 2015: Středověká odpadní jímka domu čp. 7 v Krajinské ulici v Českých Budějovicích ve výsledcích rozboru artefaktů a environmentálních analýz. Archeologické výzkumy v jižních Čechách 28. CHVOJKA O., MENŠÍK P., PROKOP V., NOVÁK J., ŠÁLKOVÁ T., FROHLICH J., MICHÁLEK J. 2014: Sídliště z mladší doby bronzové ve Zhoři na Táborsku. Archeologické výzkumy v jižnich Čechách 27, 69-85.

DESIBIO, L., ENEI, F., NARDI COMBESCURE, S., POCCARDI, G., SIA, V., LEVANTO, M. T. 2015: The Castrum Novum Project: History and Archaeology of a Roman Colony (Santa Marinella, Rome, Italy). International Journal of Archaeology 3, 62-75.

DIVIŠOVÁ, M., ŠÍDA, P. 2015: Plant use in the Mesolithic period. Archaeobotanical data from the Czech Republic in the European context - a review. Interdisciplinaria Archaeologica, Natural Sciences in Archaeology VI/1/2015, 95-106.

ENEI, F. 2013a: Santa Severa. Tra legenda e realtá storica. Santa Marinella.

ENEI, F. 2013b: Castrum Novum. Storia e archeologia di una colonia romana nel territorio di Santa Marinella. Quaderno 2, GATC 2013. Santa Marinella.

FRÖHLICH, J., CHVOJKA, O., JOHN, J., MICHÁLEK, J., POKORNÁ, K., ŠÁLKOVÁ, T., BENEŠ, J. 2014: Dvě fortifikace u Brloha na Písecku. Archeologické výzkumy v jižnich Čechách 27, 87-112.
HLÁSEK, D., HOUFKOVÁ, P., KOVAČIKOVÁ, L., MAJER, A., NOVÁK, J., PAVELKA, J., BEŠTA, T., ŠÁLKOVÁ, T. 2014. The Use of Environmental Methods for Studying the Fortification, Economic System and Natural Environment of a Hillfort from the Beginning of the Middle Bronze Age at Vrcovice, Czech Republic. Interdisciplinaria Archaeologica, Natural Sciences in Archaeology V/1/2014, 31-47.

HLÁSEK, D., CHVOJKA, O., ŠÁLKOVÂ, T., FRÖHLICH, J., HOUFKOVÁ, P., KOVAČIKOVÁ, L., MAJER, A., MENŠÍK, P., MICHÁLEK, J., NETOLICKÝ, P., NOVÁK, J., PAVELKA, J., PETŘíK, J., SOSNA, D. 2015: Vrcovice. Hradiště z počátku střední doby bronzové. Archeologické výzkumy v jižních Čechách. Supplementum 10. České Budějovice.

HOUFKOVÁ, P., BUMERL, J., POSPÍŠIL, L., KARLÍK, P., BENEŠ, J., BERNARDOVÁ, A., HRABALÍKOVÁ, M., JANEČKOVÁ MOLNÁROVÁ, K., HEJCMAN, M. 2015: Origin and development of long-strip field patterns: a case study of an abandoned medieval village in the Czech Republic, Catena 135, 83-91.

KOČÁR, P., BENEŠ, J., PREUSZ, M., VANĚČEK, Z. 2015: Ječmen a ječný slad ve středověku a raném novověku v českých zemích. Kvasný prümysl 61/5, 153-158.

KOČÁR, P., POKORNÁ, A., ŠÁLKOVÁ, T., ŽÁČKOVÁ, P., KOMÁRKOVÁ, V., VANĚČEK, Z., NOVÁK, J., (in prep.): Checklist of wild-growing herbaceous plants in prehistory of the Czech Republic: New perspective based on archaeobotanical evidence.

KODÝDKOVÁ, K., BENEŠ, J., KOMÁRKOVÁ, V., PACLÍKOVÁ, K. 2013: Pilot archaeobotanical analysis of the sediment the well 112 in Pyrgi, Santa Severa, Archaeologia Maritima Mediterranea. An International Journal on Underwater Archaeology 10, 181-188.

KREJČÍ, J., ARIAS, K., VYMAZALOVÁ, H., POKORNÁ, A., BENEŠ, J. 2014: The Mastaba of Werkaure, Volume 1, Tombs AC 26 and 32 - Old Kingdom strata. Czech Institute of Egyptology, Faculty of Arts, Charles University in Prague, Prague.

MADANI, I., TAHIR, Y. F., HAMDEEN, H. M., POKORNÁ, A., POKORNYY, P. 2015: Vegetation ecology and taxonomy of El-Ga'ab area, North-Western Sudan. European Academic Research 3.3, 2927-2943.

NOVÁK, J. 2014a: Antrakologická analýza raně středověkých objektů z lokality Turnov-Maškovy zahrady. Archeologie ve středních Čechách $18,865-868$.

NOVÁK, J. 2014b: Antrakologická a makrozbytková analýza vrcholně středověkých objektů ze Starého Místa u Jičína. Archeologie ve střednich Čechách 18, 357-361.

POKORNÁ,A., HOUFKOVÁ, P., NOVÁK, J., BEŠTA, T., KOVAČIKOVÁ, L., NOVÁKOVÁ, K., ZAVŘEL, J., STAREC, P., 2014: The oldest Czech fishpond discovered? An interdisciplinary approach to reconstruction of local vegetation in mediaeval Prague suburbs. Hydrobiologia 730,191213.

POKORNÁ, A., KUNCOVÁ, K. 2015: Species responses to environmental gradients in a semi-desert zone of Sudan: calibrating recent vegetation data for further archaeobotanical reconstructions. In: Proceedings of IWAA, Modena, 2015. 77-79, Modena.

POKORNÁ, A., SUKOVÁ, L., VARADZIN, L., NOVÁK, J., JUŘIČKOVÁ, L., HAVELKOVÁ, P., POKORNÝ, P. 2014: An early post-Meroitic burial of an archer at Jebel Sabaloka: Multidisciplinary investigation. In: Proceedings of the $13^{\text {th }}$ International Conference for Nubian Studies, Neuchatel, Switzerland, 2014. Neuchatel.

POKORNÝ, P., POKORNÁ, A. 2013: "Agoul landscapes" in the oases of the Western Desert of Egypt: Ecology and palaeoecology of vegetation mounds in El-Hayz, Southern Bahriya. In: Dospěl, M., Suková, L. (Eds.): Bahariya Oasis. Recent Reserarch into the Past of an Egyptian Oasis. Charles University in Prague, Faculty of Arts, Prague, 113-130.

PRACH K., JÍROVÁ A. DOLEŽAL J. 2014. Pattern of succession in oldfield vegetation at a regional scale. Preslia 86, 119-130.

PREUSZ, M., BENEŠ, J., KOVAČIKOVÁ, L., KOČÁR, P., KAŠTOVSKÝ, J. 2014: What did they Eat, what did they Drink, and from what? An Interdisciplinary Window into the Everyday Life of the Early Modern Burgher's Household in Český Krumlov (Czech Republic). Interdisciplinaria Archaeologica, Natural Sciences in Archaeology $\mathrm{V} / 1 / 2014,59-77$.

PROSTŘEDNÍK, J., HADACZ, R., HOUFKOVÁ, P., NOVÁK, J. 2014: Bioarcheologický výzkum skalní dutiny Velbloud v Klokočských skalách. Archeologie ve středních Čechách 18, 141-154. 
ŠÁlKOVÁ, T., CHVOJKA, O., ZAVŘEL, P. 2014: Archäobotanische Untersuchungen in vorgeschichtlichen Siedlungen Südböhmens. Fines Transire 23, 57-74.

ŠÁLKOVÁ, T., BEZDĚK, A., BŘEZINOVÁ, H., FARKAŠOVÁ, K., HOUFKOVÁ, P., CHVOJKA, O., JOHN, J., KONÍK, P., KOVAČIKOVÁ, L., MICHÁLEK, J., NOVÁK, J., PAVELKA, J., ŠULÁKOVÁ, H., BEŠTA, T., MYŠKOVÁ, E., WEITER, L., ZRONEK, P. in print Bioarchaeological reconstruction of the funeral rite - case study based on organic material from the Hallstatt Period tumulus at the site Zahrádka (South Bohemia, Czech Republic). Památky archeologické.
ŠÁlKOVÁ, T., HOUFKOVÁ, P., JIŘíK, J., KOVAČIKOVÁ, L., NOVÁK, J., PTÁK, M., BEŠTA, T., ČEJKOVÁ, A., MYŠKOVÁ, E. 2015: Reflection of the medieval economy in the well backfill in Písek, Bakaláře square (South Bohemia, Czech Republic). Interdisciplinaria Archaeologica, Natural Sciences in Archaeology VI/1/2015, 63-82.

ŠÍDA, P., PROSTŘEDNÍK, J., POKORNÝ, P. 2014: The Mesolithic of the Bohemian Paradise Sandstone Region. In: Sázelová, S., Hupková, A, Mořkovský, T. (Eds.): Mikulov Anthropology Meeting. The Dolní Věstonice Studies 20,117-124. 
